Розанна Бенаккьо

Университет в Падуе

Департамент лингвистических

и литературных исследований

rosanna.benacchio@unipd.it
УДК 811.163.6'28'367.625

https://doi.org/10.18485/slavistika.2018.22.1.1

оригинални научни рад примљено 02.03.2018

прихваћено за штампу 14.05.2018.

\title{
ИНТЕГРАЦИЯ ЗАИМСТВОВАННЫХ ГЛАГОЛОВ В СЛАВЯНСКУЮ ВИДОВУЮ СИСТЕМУ: РЕЗЬЯНСКИЙ ДИАЛЕКТ
}

\begin{abstract}
В статье рассматриваются морфологические средства грамматикализации глагольного вида в резьянском диалекте. Анализируется разница в поведении исконно славянской лексики, в основном прибегающей к префиксации (с перфективирующей функцией), и заимствованной лексики, прежде всего романского происхождения, где префиксация почти отсутствует и используется суффиксация (с перфективирующей функцией). Немного иначе ведет себя заимствованная лексика германского происхождения, которая в большей мере допускает префиксацию.
\end{abstract}

Ключевые слова: глагольный вид, морфология, романские и германские заимствования, резьянский диалект.

This paper examines the morphemes and morphological processes involved in the grammaticalization of aspect in the Resian dialect, with a special focus on the verbal lexicon of Romance and Germanic origin. Unlike the native Slavic verbal lexicon (which mainly shows perfectivizing preverbation), Romance loans show almost no preverbation at all, while imperfectivizing suffixation abounds. In the case of Germanic loans, on the other hand, prefixation is more frequently found.

Keywords: Verbal aspect, Morphology, Romance loans, Germanic loans, Resian.

Цель нашей работы - внести вклад в дискуссию о проблеме интеграции заимствованных глаголов в славянскую видовую систему, основываясь на материале резьянского диалекта.

Резьянский - это словенский диалект, находящийся на периферии славянской языковой системы, в северо-восточной Италии, во Фриули, на границе со Словенией. Этот диалект прожил много веков внутри романского языкового окружения, и поэтому он особенно богат иноязычной (романской) лексикой. Однако в более древнее время (примерно до XV века ${ }^{1}$ ) он потерпел сильное влияние и немецкого языка.

Как мы увидим, изучение способов грамматикализации глагольного вида в этом диалекте дает различные результаты в зависимости от того, имеем ли мы дело с исконно славянской или с иноязычной лексикой (а также, имеем ли мы дело с романской или с германской лексикой).

Как в предыдущих работах (Бенаккьо 2015; Бенаккьо, Стэнвейк, в печати) для анализа мы пользовались материалом, собранным в населенном пункте Сан-Джоржо ${ }^{2}$ (см. Steenwijk 1992: 237-338), интегрированным другими дан-

${ }^{1}$ Т.е. до падения Аквилейского патриархата, когда область Фриули отошла к Венецианской Республике (см. Benacchio 2002: 63).

${ }^{2}$ Как известно, говор населенного пункта Сан-Джорджо (по-резьянски - Била), в силу своего географического положения (ближе к выходу резьянской долины к фриульской 
ными, взятыми из Steenwijk 2005, а также из словаря, размещенного на сайте Resianica). Кроме того, мы проводили опрос информантов из Сан-Джоржо. Что касается транскрипции, она следует орфографическим правилам, рекомендуемым в Steenwijk 2005.

Мы сначала сделаем краткий обзор способов грамматикализации вида относительно исконно славянской лексики, а потом перейдем к сравнению с романской и к германской лексикой.

\section{1. Исконно славянская лексика}

\section{1 Префиксация}

Исконно славянские терминативные бесприставочные глаголы участвуют в процессе образования видовых пар в основном посредством префиксации: наряду с основной, бесприставочной, производящей формой глагола (чаще всего $\mathrm{HCB})$, появляется целый ряд производных форм (СВ), образованных посредством разных приставок. Эти дериваты могут образовывать видовые гнезда, которые содержат до десяти (и больше) глагольных форм СВ.

Только в некоторых случаях новая приставочная форма образует пару с исконной бесприставочной, и мы имеем дело с т.н. «префиксальными видовыми коррелятами»³. Это происходит (согласно т.н. «принципу Vey-Schooneveld») тогда, когда семантика префикса и производящего глагола совпадают и значение префикса (чаще всего пространственное, но также и временное, и даже более отвлеченное, метафорическое) как бы стирается, нейтрализуется. В этих случаях вторичная имперфективация не нужна и не появляется.

Обычно можно говорить только об одной «пустой» приставке, хотя бывают случаи, когда на такую роль могут претендовать две, реже и три приставки ${ }^{4}$. В большинстве случаев, однако, приставки придают базовой форме определенное лексическое значение, и новый приставочный глагол обязан создать себе партнера с тем же значением посредством т.н. вторичной имперфективации. Об этом, известном во всех славянских языках явлении, будем говорить ниже. В качестве примера, приведем следующее словообразовательное гнездо, образованное на основе простого глагола (simplex) nuсать:

территории), испытал влияние контактирующего романского окружения в большой мере, больше, чем другие варианты резьянского диалекта. В частности, в Сан-Джорджо - Била очень распространено употребление фриульского языка.

${ }^{3}$ См. также термин «естественные перфективы» (Natural Perfectives), противопоставляемый термину «специализированные перфективы» (Specialized Perfectives), употребляемые в работах Л. Янды (см. Janda et al. 2013).

${ }^{4}$ Такое явление, хорошо известное и в русском языке, стало предметом пристального внимания в исследованиях последних лет, ведущихся на языковом материале, находящемся в Интернете и в Национальном Корпусе Русского Языка НКРЯ в частности. Среди них особое место занимают исследования группы CLEAR о вариативности приставок (Prefix Variation), См. Janda et alii 2013: 139-162. См. по этому поводу Зализняк, Микаэлян 2012 (перепечат. в книге Зализняк, Микаэлян, Шмелев 2015: 261 и сл.), Петрухина 2014: 259 и др. 


\begin{tabular}{|c|c|}
\hline $\begin{array}{l}\text { pïsat } \\
\text { napisat }_{\text {св }}\end{array}$ & ‘писать / написать’ \\
\hline $\begin{array}{l}\text { pripïsat }_{\text {св }} \\
\text { pripiš }_{\text {üwat }}\end{array}$ & 'переписывать / переписать' \\
\hline $\begin{array}{l}\text { zapïsat }_{\mathrm{c}} \\
\text { zapišüwat }_{\text {нсв }}\end{array}$ & ‘записывать / записать' \\
\hline $\begin{array}{l}\text { pudpïsat }_{\text {св }} \\
\text { pudpišüwat }_{\text {нсв }}\end{array}$ & ‘подписывать / подписать’ \\
\hline
\end{tabular}

Нетерминативные бесприставочные глаголы тажке могут порождать производные формы СВ посредством префиксации. В данном случае, однако, приставочные глаголы обозначают способы действия. Это в основном префиксы $z a$ - (инхоативный с.д.) и ро- (делимитативный с.д.). См.:

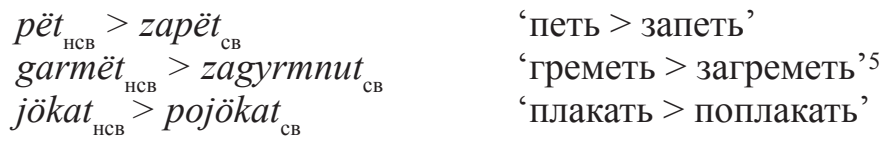

Однако такие случаи появляются редко, намного реже, чем в русском языке.

\section{2 Суффиксация}

Гораздо реже для создания видового коррелята терминативные бесприставочные исконно славянские глаголы прибегают к суффиксации, играющей имперфективирующую фунуцию Это 'первичная имперфективация' по определению Исаченко (1960: 170). Исходный бесприставочный глагол играет роль перфективного члена пары (выражающего достижение предела однократного действия), а новый, также бесприставочный - имперфективного (выражающего процесс, ведущий к пределу или многократность).

Имперфективация может реализоваться прибавлением суффикса $-a$-, хотя чаще суффикс реализуется как -wa- (или -ja-), гле $w$ (или $j$ ) является вставным («эпентетическим») элементом, устраняющим ятус (Исаченко 1960: 193)6. Нужно добавить также, что очень часто происходит палатализация согласно-

\footnotetext{
${ }^{5}$ Стоит заметить, что в данном случае, кроме префикса, к базовому глаголу прибавляется и суффикс -ну-. Такое, совсем не редкое, явление, требует отдельного исследования совместно с изучением суффикса -нy-, также играющего важную роль в процессе грамматикализации глагольного вида в резьянском. Этой теме будет посвящена отдельная работа.

${ }^{6}$ Случаи первичной суффиксации посредством суффикса - $\ddot{w} w a$ - совсем редки (точно так, как было редким, употребление суффикса -ova- в такой функции в старославянском языке (Schuyt 1990: 7, 29-34 е passim). Это в основном глагол kupüwat ${ }_{\text {нсв }} \leftarrow$ küpit ' 'покупать / купить' присутствующий в той же форме уже в старославянском, и сохранившийся также в словенском (kupovati / kupiti) и в серьбо-хорватском (kupovati / kupiti). См. также skučüwat $\leftarrow s k u c ̌ y t$ св 'прыгать / прыгнуть’ и т.д.
} 
го, который предшествуюет суффиксу. Могут появляться и другие изменения в корне, отражающие фонетическое развитие и характерные для сложного резьянского вокализма. См.:

\begin{tabular}{|c|c|}
\hline 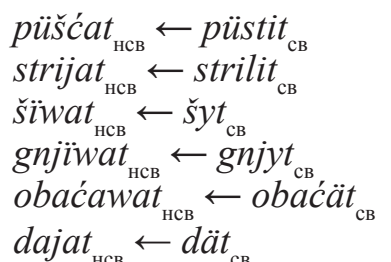 & $\begin{array}{l}\text { ‘пускать / пустить' } \\
\text { 'стрелять / выстрелить' } \\
\text { 'шить / сшить' } \\
\text { 'гнить / сгнить' } \\
\text { 'обещать' } \\
\text { 'давать / дать' }\end{array}$ \\
\hline
\end{tabular}

В целом, примеры первичной суффиксации в резьянском диалекте редки, хотя, казалось, они появляются чуть чаще, чем в русском языке. Они являются остатками более древнего этапа процесса грамматикализации глагольного вида, когда имперфективирующий суффикс - $a$ - находился «на грани» акциональной (дуративной) и аспектуальной функций (см. по этому поводу Мауо 1985: 20, Ruvoletto 2016: 116-117).

Что касается вторичной имперфективации, в резьянском диалекте она реализуется в основном посредством суффикса -ӥva- (pres. - $u j$-), часто сопровождающегося палатализацией предыдущего согласного. Кроме приведенных выше глагольных форм, производных от глагола писать (типа pripišüwat $t_{\text {нсв }} \leftarrow$ pripïsatсв $\left(\leftarrow\right.$ piss $_{\text {нсв }}$ и т.д.), см. также dilüwat $_{\text {нсв }} \leftarrow$ zdelat $_{\text {св }}\left(<\right.$ delat $\left._{\text {нсв }}\right)$ 'рожать / родить', namažüwat $_{\text {нсв }} \leftarrow$ namazat $_{\text {св }}\left(\leftarrow\right.$ mazat $_{\text {нсв }}$ ' 'намазывать / намазать)', и др.

Встречаются и случаи, когда вторичная имперфективация осуществляется посредством суффикса -wa- (или -ja-), но они редки. См.:

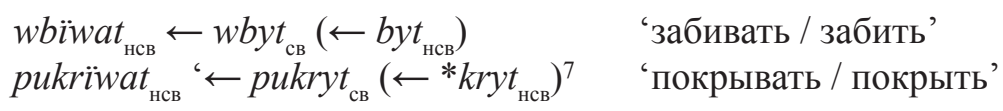

Итак, если принимать во внимание способы грамматикализациии вида (точнее, образования видовых пар) исконно славянских глаголов, наблюдается полное совпадение с общими принципами глагольной деривации, действующими для большинства славянских языков. Совсем по-другому представляется ситуация заимствованной лексики, о чем будет сказано ниже.

\section{2. Заимствованная лексика}

\section{1 Романская лексика}

Анализируя глаголы романского (фриульского, итальянского а также венецианского ${ }^{8}$ ) происхождения, мы обнаружили противоположную картину: для

\footnotetext{
${ }^{7}$ Глагол kryt в безприставочной форме не встречается в резьянском диалекте, однако

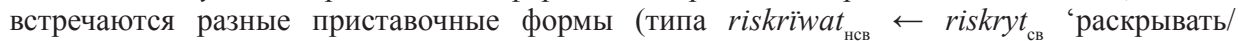

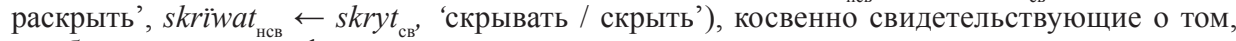
что бесприставочная форма раньше существовала.

${ }^{8}$ Как было подробно сказано в предыдущих работах (см., напр., Бенаккьо, Стэнвейк, в
} 
терминативных глаголов продуктивна суффиксация. Иными словами, в большинстве случаев заимствованные терминативные глаголы воспринимаются как глаголы, выражающие результативность (а также, хотя и реже, инцептивность), которые обязаны создать себе партнера НСВ посредством именно имперфективирующей суффиксации (это ‘первичная имперфективация’, о которой говорилось выше).

Словообразовательный способ суффиксации - тот же самый, который мы отметили для исконно славянской лексики, точнее это суффикс -wa- $(<-a-)$, которому предшествует либо гласное $a$, либо $\ddot{i}$.

Как показал Х. Стэнвейк (Бенаккьо, Стэнвейк, в печати), в первом случае (-awa-) мы имеем дело с резьянскими глаголами с инфинитивом на -ät, восходящими к I и II (а также, хотя весьма редко к III) романскому спряжению. Эта словообразовательная модель реализуется с найбольшей частотностью. Ср.:

\begin{tabular}{|c|c|c|}
\hline$a c ̌ e t a w a t_{\text {нсв }}$ & $\leftarrow$ ačetät $t_{\mathrm{cB}}$ (ср. ит. accettare) & ‘принимать / принять’ \\
\hline priparawat $_{\text {нсв }}$ & $\leftarrow$ priparät $_{\mathrm{cв}}$ (ср. ит. preparare) & ‘готовить / подготовить’ \\
\hline provawat $_{\text {нсв }}$ & $\leftarrow$ provät $_{\mathrm{cв}}$ (ср. ит. provare) & ‘пробовать / попробовать’ \\
\hline provokawat $_{\text {нсв }}$ & $\leftarrow$ provokawat $_{\mathrm{cв}}$ (ср. ит. provocare) & ‘провоцировать / спровоцировать’ \\
\hline$\check{s} k o p j a w a t_{\text {нсв }}$ & $\leftarrow \check{s}$ opijat $_{\mathrm{cв}}$ (ср. ит. scoppiare) & ‘лопаться / лопнуть’ \\
\hline bandonawat $_{\text {нсв }}$ & $\leftarrow$ bandonat $_{\mathrm{cв}}$ (ср. ит. abbandonare) & ‘бросать / бросить’ \\
\hline intarašawat $_{\text {нсв }}$ & $\leftarrow$ intarašät ${ }_{\mathrm{cв}}$ (ср. ит. interessare) & ‘интересовать / заинтересовать' \\
\hline prižantawat $_{\text {нсв }}$ & $\leftarrow$ prižantät $_{\mathrm{cв}}$ (ср. ит. presentare) & ‘представлять / представить' \\
\hline rivinawat ${ }_{\text {нсв }}$ & $\leftarrow$ rivinät $_{\mathrm{cв}}$ (ср. ит. rovinare) & ‘разрушать / разрушить' \\
\hline$\breve{s k a r c a w a t}_{\text {нсв }}$ & $\leftarrow \check{s} \operatorname{arcät}_{\text {св }}$ (ср. ит. scherzare) & ‘шутить / пошутить’ \\
\hline šparnjawat & $\leftarrow \check{s p a r n j a ̈ t ~}{ }_{\mathrm{cв}}$ (ср. ит. risparmiare) & ‘сберегать / сберечь' \\
\hline štufawat & $\leftarrow$ štufät $t_{\text {св }}$ (ср. ит. stufare) & ‘надоедать / надоесть’ \\
\hline špindawali & $\leftarrow \check{s}$ pindät $t_{\mathrm{cв}}$ (ср. ит. spendere) & ‘тратить / истратить деньги’ \\
\hline solodawat $_{\text {нсв }}$ & $\begin{array}{l}\text { solodawat }_{\mathrm{Hв}} \leftarrow \text { solodät } \\
(\mathrm{cp} \text {. ит. salutare })\end{array}$ & 'приветствовать / поприветствовать' \\
\hline
\end{tabular}

Во втором случае (-̈̈wa-) речь идет о резьянских глаголах с инфинитивом на $-y t$.

Данный суффикс характерен для глаголов, принадлежащих к IV романскому спряжению:

печати) трудно четко различать эти три источника, так как в большинстве случаев ярких фонологических или семантических различий между ними не существует. В данной работе мы будем давать итальянский перевод (как возможный источник), а фриульскую форму будем указывать только в тех случаях, когда глагол в итальянском языке (и в венецианском) просто не существует. При написании фриульских форм мы будем опираться на неизданную работу Х. Стэнвейка о заимствованных глаголах в резьянском.

9 Другие примеры можно увидеть в Бенаккьо 2009 и в Бенаккьо, в печати. 


\begin{tabular}{|c|c|c|}
\hline špartïwat ${ }_{\text {нсв }}$ se & $\leftarrow$ spartyt ${ }_{\mathrm{cB}}$ se (ср. ит. partire) & ‘отправляться / отправиться’ \\
\hline binidïwat & $\leftarrow$ binidyt $_{\mathrm{cв}}$ (ср. ит. benedire) & 'благословлять / благословить' \\
\hline maladïwat $_{\text {нсв }}$ & $\leftarrow$ maladyt $_{\mathrm{cB}}($ ср. ит. maledire $)$ & ‘проклинать / проклясть' \\
\hline$z a w d y t_{\text {нсв }}$ & $\leftarrow z_{\text {awdiwat }}$ (ср (ср. ит. esaudire) & ‘исполнять / исполнить’ \\
\hline
\end{tabular}

Отметим, что в обоих случаях (как в случае суффикса -awa-, так и -їwa-) у производящих, заимствованных глаголов ударение никогда не падает на корне, а всегда на окончании.

Следует также упомянуть особую группу резьянских глаголов с инфинитивом на -inat, восходящим к III романскому спряжению. Происхождение данного суффикса пока неизвестно. Можно, однако, отметить две особенности: во-первых, производные посредством данного суффикса - это исключительно глаголы «книжной» сферы; во-вторых, это глаголы с ударением на корне, а не на окончании. Кроме редчайших случаев (нами был найден только один: sucedinüwat se < sucëdinat se 'происходить'), глаголы этой группы ведут себя как биаспективы. Вот некоторые примеры ${ }^{10}$ :

\begin{tabular}{|c|c|c|}
\hline dišsperdinat $_{\sigma u}$ & (ср. ит. disperdere) & 'растрачивать / растратить' \\
\hline dištïngvinat $_{\sigma}$ & (ср. ит. distinguere) & ‘отличать / отличить' \\
\hline dividinat $_{\sigma u}{ }^{\circ}$ & (ср. ит. dividere) & ‘делить / разделить’ \\
\hline finğinat $_{б и}$ & (ср. ит. fingere) & ‘делать / сделать вид’ \\
\hline fondinat $_{б u}$ & (ср. ит. fondere) & 'растворяться / раствориться' \\
\hline mövinat & (cp. ит. muovere) & ‘двигать / двинуть' \\
\hline parvidinat $_{\sigma u}$ & (ср. ит. prevedere) & ‘предвидеть’ \\
\hline proponinat $_{\sigma u}$ & (cp. ит. proporre) & 'предлагать / предложить' \\
\hline
\end{tabular}

Префиксация (с противоположной функцией, т.е. создания коррелята СВ) играет весьма незначительную роль в процессе грамматикализации глагольного вида у романских заимствованных терминативных глаголов. Она носит исключительный характер. Это случаи, например, следующих пар:
ribižät ${ }_{\text {нсв }} /$ zribižä $_{\text {св }}$
(см. фриул. ribizzâ)
tičät ${ }_{\text {нсв }} /$ stičät $_{\text {св }}$
(см. фриул. ticiâ) ${ }^{11}$
‘ тереть / натереть'
'жечь / сжечь (дрова)'

В данных случаях употребляется префикс $z-/ s$-, являющийся самым употребительным префиксом с чистовидовой функцией в резьянском диалекте (Бенаккьо 2015). Этот префикс имеет параллель, хотя только на лексическом уровне, в фриульском (и итальянском) префиксе $s$-. Нельзя исключить, что эти два фактора способствовали применению такого, вообще редко употребляемого, способа образования видовой пары.

\footnotetext{
${ }^{10}$ См. также Бенаккьо, Стэнвейк, в печати. Теме глаголов на -inat, и вообще биаспективов в резьянском диалекте будет уделено внимание в отдельном исследовании.

11 Что касается второго глагола, встречается также форма zatičät 'подбрасывать / подбросить дров в огонь', сp. «Ni so lepo zatičäli».
} 
Встречаются, правда, и некоторые заимствованные глагольные формы, которые интегрировались в резьянскую видовую систему посредством других префиксов, а именно $v i-, d u-/ d o-, w(o)$. Это префиксы, охарактеризованные ярким пространственным значением, которые, присоединяясь к заимствованной бесприставочной форме, создают новые лексические образования, чаще всего, принадлежащие к бытовому языку. Это не «естественные», а «лексические» перфективы, которые подвергаются вторичной имперфективации. Это, например, случай глагола viškarpalät ${ }_{\text {св }}$ / viškarpalawat долотом' от фриул. scarpelâ 'долбить долотом'. Исконная, бесприставочная форма škarpalät $t_{\text {св }}$ также встречается в резьянском, образуя, как правило, пару со суффиксальной имперфективной формой škarpalawat ${ }_{\text {нсв }}$.

Подобное можно сказать о паре durijavät / осуществить' (в других резьянских говорах, появляющейся как durivät $t_{\text {св }}$ / durivawat ${ }_{\mu \mathrm{c}}$ ), которая, посредством префикса $d u-/ d o$, связана с парой rivät ${ }_{\mathrm{cB}} /$

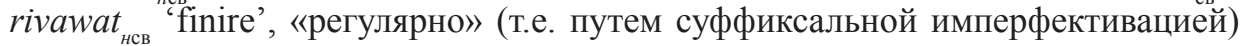
образованной от фриул. rivâ (см. выше).

Встречаются и случаи «мнимых» префиксов. См.: žbridinät $t_{\mathrm{cB}} /$ bridinät $_{\text {нсв }}$ $<$ öwco > 'разорвать / разрывать (на части) <овцу>' от фриул. sbridinâ. Как отмечает Стэнвейк (Бенаккьо, Стэнвейк, в печати), глагол заимствован от фриул. sbridina $^{12}$. В фриульском языке глагол * bridinâ не существует. Видимо резьянский диалект, на основе (очень употребительного) исконно славянского префикса $z-/ s$-, реинтерпретировал по своей модели заимствованный материал (депрефиксация).

См. также: žbričolät $t_{\text {св }}$ / bričolawät $t_{\text {нв }}$ 'накрошить/крошить' (от ит. sbriciolare), хотя, по правилу, здесь в качестве формы НСВ должна была бы встретиться не форма bričolät, a bričolawät. Возможно, bričolät и была первоначальной формой $\mathrm{HCB}$, полученной посредством депрефиксации, но потом появилась вторая, полученная по (очень распространенной, продуктивной) модели суффиксации.

Что касается нетерминативных глаголов, можно предположить, что от них образуются способы действия. Однако «надежных» случаев в применении к заимствованным глаголам пока не нашлось. Более того, как мы уже видели по поводу исконно славянских глаголов, в резьянском диалекте морфологическое выражение способов действия - это вообще редкое явление.

\section{2 Германская лексика}

Заимствованных глаголов германского происхождения в резьянском диалекте гораздо меньше, чем романских. Очень часто невозможно с точностью определить, является ли глагольная форма заимствованной прямо из немецкого языка (в основном из средне-верхненемецкого, но также и с древне- и ново- верхненемецкого; дальше, соответственно, свн., двн. и нвн.) или через романское (точнее, фриульское) посредство. Поэтому, в отличие от того, что было сделано для

12 Что касается присутствия $\check{z}$ - вместо $s$ - в заимствованном глаголе, следует отметить, что превращение свистящих $s / z$ в шипящие $\check{s} / z$, особенно перед взрывными согласными, это явление, распространенное в резьянском диалекте в процессе заимствования слов (ср., например, peз. dišperdinat, dimoštrat, koštat, ит. disperdere, dimostrare, costare). См. Бодуэн де Куртенэ 1875, § 57. 
заимствований романского происхождения, в данном случае мы постарались уточнить источник и хронологию анализируемых заимствований, основываясь на работах Безлая (Bezlaj 1977-2007) и Штридтер-Темпс (Striedter-Temps 1963). Отметим также, что мы исключили из анализа такие, более древние заимствованные формы, как, например, küwat 'готовить/приготовить' и pöstit 'поститься', засвидетельствованные и в других славянских языках.

Итак, несмотря на небольшое количество примеров, можно сказать, что заимствованные (терминативные) глаголы германского происхождения склонны к префиксации в большей мере, чем романские. См., например, следующие пары:

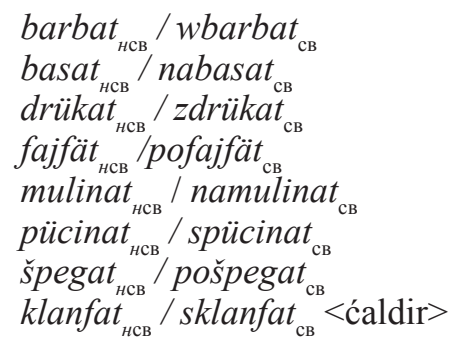

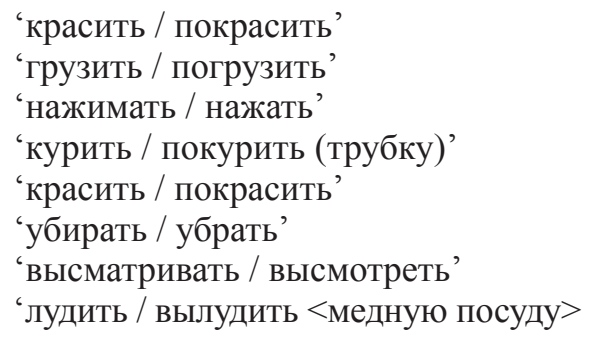

Первая пара, barbat / wbarbat, по всей вероятности, восходит к двн. varawa или к свн. varwe (см. вarva: Bezlaj I: 12, Striedter-Temps 1963: 80; ср. нем. Farbe). Префикс $w$ - в данном случае мог бы отражать как $*_{o-}$ так $* u$ - и $*_{v-}{ }^{13}$. Однако, по всей вероятности, здесь мы имеем дело с префиксом $о-$, играющем роль пустой приставки, чья семантика гармонизирует с семантикой самого глагола. Правда, в данном случае нельзя было бы говорить о «настоящем» заимствованном немецком глаголе, а о глаголе, полученном посредством резьянской «адаптации» немецкого существительного, что и могло бы обеспечить новой глагольной форме бо́льшую степень адаптации к славянской системе. То же самое надо сказать по поводу глаголов fajfät / pofajfät и klanfat / sklanfat. Первый, по всей вероятности, заимствован из нвн. Pfeife 'трубка' (см. fajfa: Bezlaj I: 127, Striedter-Temps 1963: 113), а второй - из свн. *klampfe (см. klamfa: StriedterTemps 1963: 150; ср. нем. Klammer 'железный крючок'). И в этом случае оба глагола образуют пару посредством «пустого» префикса: в первом случае это po-, во втором $s$-.

Следующие же глаголы являются настоящими заимствованными глаголами. Например, пара basat / nabasat va33en (см. basati Bezlaj I: 12, StriedterTemps 1963: 89; cp. нем. fassen). Пара образуется путем префикса na-, имеющего сходную с производящим глаголом семантику, отражая таким образом закон Вея-Схонефельда.

То же самое можно сказать о паре mulinat / namulinat, восходящей к свн. (или к нвн.) ${ }^{14}$ malen (см. malati Bezlaj II: 162, Striedter-Temps 1963: 175).

\footnotetext{
${ }^{13} \mathrm{O}$ возможной нейтрализации, в определенных позициях гласных $o$ и $u$ см. подробнее Бенаккьо, Стэнвейк, в печати.

${ }^{14}$ По мнению Хана Стэнвейка (устное сообщение), если судить по вокализму резьянского глагола, более вероятной следует считать первую гипотезу, т.е. что заимствование имело
} 
Что касается špegat / pošpegat по всей вероятноси имеется дело с глаголом, заимствованным с свн. spëуen (см. špegati: Bezlaj IV: 97, Striedter-Temps: 223). Интересно, что в качестве формы СВ очень часто встречается также форма, образованная не только посредством префикса, но также и суффикса -нy-: pošpegnut («An je pošpegnul anu jë wbižal proč», «Pošpegni!»). По мнению некоторых информантов, суффикс -ну- «прибавляет» значение мгновенности; по мнению других, он просто «усиливает» значение законченности действия (см. выше сноску 5).

В случае глагола pücinat / spücinat, восходящий к нвн. putzen (см. pucat: Striedter-Temps: 202) и drükat / zdrükat, восходящий к свн. drucken / drücken (см. drukniti: Striedter-Temps: 111), употребляется префикс s-/z-, самый употребительный резьянский префикс с чисто перфективирующей функцией.

Надо, однако, признаться, что среди заимствованных глаголов германского происхождения, наряду с приставочными глагольными парами, встречаются также (хотя в меньшем количестве) бесприставочные пары суффиксального типа, подобно тому, что происходит с заимствованными глаголами романского происхождения. См., например, следующие глаголы:

$\begin{array}{lll}\text { šinküwat }_{\text {нсв }} \leftarrow & \text { šenkat }_{\text {св }} & \text { 'дарить / подарить' } \\ \text { lunüwat }_{\text {нвв }} \leftarrow & \text { lonat }_{\text {св }} & \text { 'благодарить / поблагодарить' } \\ \text { žignüwat }_{\text {нсв }} \leftarrow & \text { žëgnat }_{\text {св }} & \text { 'благословлять / благословить' }\end{array}$

Первый глагол восходит к свн. или нвн. schenken (см. šenkati: Bezlaj IV: 32, Striedter-Temps 1963: 217), второй к двн. lônôn или свн. lônen (см. lon, lonati: Bezlaj, II: 149, Striedter-Temps 1963: 170), а третий к двн. seganōn или свд. sëgenen (см. žegen, žegnati: Bezlaj IV: 441, Striedter-Temps 1963: 250). Сопоставляя эти последние три случая с предыдущими примерами, мы не находим хронологических причин, объясняющих особый путь интегрирования этих глаголов в систему (использование механизма суффиксации вместо префиксации). На данном этапе мы можем только рассматривать их как «исключение из правила», предполагающего вхождение заимствованных глаголов в систему путем префиксации.

\section{Заключение}

Сравнение способов грамматикализации глагольного вида исконной резьянской лексики с одной стороны, и иноязычной (романской и германской) лексики - с другой, дало интересные результаты.

Что касается исконной лексики мы наблюдали полное соответствие общим принципам славянской глагольной деривации: самый типичный способ образования новых пар - это перфективирующая префиксация, в то время как имперфективирующая (первичная) суффиксация занимает второстепенное место (в отличие от вторичной имперфектизации, которая, как и в других славянских языках, занимает ключевое место в видообразовании).

Практически противоположную картину мы наблюдали, анализируя иноязычные глаголы романского происхождения: терминативные глаголы регулярно место в более древнюю эпоху.

Славистика XXII/1 (2018) 
интегрируются в резьянскую видовую систему посредством суффиксации. Они воспринимаются как глаголы, выражающие результативность (или инцептивность), которые обязаны создать себе партнера НСВ посредством первичной имперфективирующей суффиксации.

Немного иначе ведут себя терминативные глаголы германского происхождения. Хотя в современном резьянском диалекте примеров таких глаголов не много, можно все-таки наблюдать отсутствие того «запрета» на перфективирующую суффиксацию, который характеризует романские глаголы. Возможно, это объясняется тем, что глаголы германского происхождения были заимствованы в более древнюю эпоху и имели больше времени для адаптации к заимствующей глагольной системе. Другая причина кроется, наверное, в том, что префиксация как таковая - это явление широко известное (хотя только на лексическом уровне) и в германской языковой системе. Возможно, ее употребление воспринималось как менее 'чуждое' в применении к этой лексике, чем к романской.

Эти результаты вполне соответствуют результатам исследований, проведенных на материале других славянских языков, бытующих на периферии славянского языкового ареала: с одной стороны, молизско-славянский микроязык, контактирующий с романским языковым ареалом, для создания видовых пар прибегает к (имперфективирующей) суффиксации, с другой, бургенландско-хорватский и верхнелужицкий, контактирующие с германским языковым ареалом, предпочитают префиксацию (см. Breu 2003, 2005, Брой и др., в печати).

\section{Использованная литература}

Бенаккьо, Розанна. «Морфологическое проявление вида в резьянском диалекте: префиксация и суффиксация». [В:] М. Китадзё (ред.) Аспектуальная семантическая зона: типология систем и сценарии диахронического развития. Киото 2015, 21-26.

Бенаккьо, Розанна, Хан Стэнвейк. «Грамматикализация глагольного вида в резьянском диалекте: исконно-славянская и романская лексика». [In:] R. Benacchio, A. Muro, S. Slavkova (eds.) The role of prefixes in the formation of aspectuality. Issues of grammaticalization. Firenze: Firenze University Press, 2017, 23-39.

Бодуэн де Куртенэ, Иван А. Опыт фонетики резьянских говоров. Варшава: Э. Венде и К - Петербург: Д. Е. Кожанчиков, 1875.

Брой, Вальтер, Ленка Шольце, Малинка Пила. «Видовые приставки в языковом контакте (на материале молизско-славянско, резьянского и верхнелужицкого микроязыков». [In:] R. Benacchio, A. Muro, S. Slavkova (eds.) The role of prefixes in the formation of aspectuality. Issues of grammaticalization. Firenze: Firenze University Press, 2017, 59-84.

Зализняк, Анна А., Ирина Л. Микаэлян, Алексей Д.Шмелев. Русская аспектология: в защиту видовой пары. Москва: Языки славянской культуры, 2015.

Исаченко, Александр В. Грамматический строй русского языка в сопоставлении с словацким. Морфология. II. Братислава: Изд. Словацкой академии наук, 1960.

Петрухина, Елена В. «Русский вид как морфологическая деривационная категория в контексте современных исследований видовой коррелятивности». Scandoslavica 54, 2014: 253-274.

Benacchio, Rosanna. I dialetti sloveni del Friuli tra periferia e contatto. Udine: Società Filologica Friulana, 2002.

Benacchio, Rosanna. "Il contatto slavo-romanzo nel croato del Molise e nei dialetti sloveni del Friuli». [In:] L. Scholze, B. Wiemer (Hrsg.) Von Zuständen, Dynamik und Veränderung 
bei Pygmäen und Giganten. Festschrift für Walter Breu zu seinem 60. Geburtstag [Diversitas Linguarum 25]. Bochum: Universitätsverlag Dr. N. Brockmeyer, 2009.

Benacchio, Rosanna. "La morfologia aspettuale nel dialetto resiano: lessico verbale di origine slava e romanza a confronto". [In:] Pino Marco Pizzo (Hrsg.) Die Slavia im totalen Sprachkontakt mit germanischen und romanischen Varietäten - historische Textzeugen und zeitgenössische Kleinsprachen. [Arbeiten und Texte zur Slavistik]. Berlin (im Druck).

Bezlaj, France. Etimološki slovar slovenskega jezika. I-V. Ljubljana: Mladinska knjiga, 1976-2007.

Breu, Walter. "Flexivischer und derivativer Verbalaspekt im Moliseslavischen". [In:] T. Berger, K. Gutschmidt (Hrsg.) Funktionale Beschreibung slavischer Sprachen [Slavolinguistica 5]. München: Kubon \& Sagner, 2003.

Breu, Walter. "Verbalaspekt und Sprachkontakt. Ein Vergleich der Systeme zweier slavischer Minderheitensprachen (SWR/MSL)". [In:] S. Kempgen (Hrsg.) Slavistische Linguistik 2003, München: Kubon \& Sagner, 2005.

Janda, Laura et alii. Why Russian Aspectual Prefixes aren’t empty. Prefixes als Verb Classifiers. Bloomington Indiana: Slavica Publishers, 2013.

Mayo, Peter J. The morphology of aspect in seventeenth-century Russian (based on texts of the Smutnoe vremja). Columbus Ohio: Slavica Publishers, 1985.

Ruvoletto, Luisa. I prefissi verbali nella Povest'vremennych let. Firenze: Firenze University Press, 2016. [Biblioteca di studi slavistici 33].

Schuyt, Roel. The morphology of Slavic verbal aspect. A descriptive and historical study. Amsterdam - Atlanta GA: Rodopi, 1990. [Studies in Slavic and general linguistics 14].

Steenwijk, Han. The Slovene dialect of Resia. San Giorgio. Amsterdam - Atlanta GA: Rodopi, 1992. [Studies in Slavic and General Linguistics 18].

Steenwijk, Han. Ortografia resiana. Padova: CLEUP, 2005.

Steenwijk, Han. Piccolo dizionario ortografico resiano/Mali bisidnik za tö jošt rozajanskë pïsanjë. Padova: CLEUP, 2005.

Striedter-Temps, Hildegard. Deutsche Lehnwörter im Slovenischen. Wiesbaden, Otto Harrassowitz 1963.

Resianica http://147.162.119.1:8081/resianica/index.do 
Розана Бенакјо

\section{ИНТЕГРАЦИЈА ПОЗАЈМЉЕНИХ ГЛАГОЛА У СЛОВЕНСКИ ВИДСКИ СИСТЕМ: РЕЗЈАНСКИ ДИЈАЛЕКАТ}

\section{Резиме}

Овим својим радом желимо допринети дискусији о проблему интеграције позајмљених несловенских глагола у словенски видски систем полазећи од грађе резјанског дијалекта, једног словенског дијалекта који припада периферији словенског језичког система, а говори се у североисточној Италији, у Фриулију, на граници са Словенијом. У питању је говор који се вековима налази у романском језичком окружењу, што објашњава велико присуство у њему стране (романске) лексике.

Проучавање начина граматикализације глаголског вида у том дијалекту даје различите резултате у зависности од тога да ли се ради о изворној словенској или страној лексици. У првом случају запажамо подударност са општим принципима глаголске деривације који делују у већини словенских језика. Конкретно, беспрефиксални лимитативни глаголи улазе у процес формирања видског пара путем префиксалне творбе. Притом, префикс не само додаје мотивној основи додатно лексичко значење, већ и (што је још важније) „прецизира“, „спецификује“ основно, мање одређено, лексичко значење полазног глагола стварајући тиме основу за његову перфективацију.

Много ређе приликом формирања видског корелата у резјанском дијалекту прибегавају суфиксацији, којој се подвргава беспрефиксни глагол. Тим путем се формирају несвршени глаголи: полазни терминативни мотивни глагол без префикса постаје свршени члан видског пара (резултативни или, ређе, инцептивни према својој семантици), а лимитативни видски парњак, такође без префикса, који је изведен од њега, несвршеног је вида. Примери такве суфиксације отприлике су подједнако ретки као и у руском језику: највероватније се ради о остацима старије етапе процеса граматикализације глаголског вида, када се суфикс (-a-), помоћу којег се градио глагол несвршеног вида, судећи по свему, налазио «на граници» акционалне (дуративне) и аспектуалне функције.

Суфиксација у служби деривирања глагола несвршеног вида је веома распрострањена и када су у питању (свршени) глаголи са префиксом („секундарна имперфективација“). Као и у руском језику тај начин је најважнији када се ради о формирању и учвршћивању система видских парова, једном речју о граматикализацији категорије вида.

Приликом анализе глагола романског порекла испоставило се да је ту слика супротна - за те глаголе је продуктивнија суфиксална творба, в.: rišpundawat < rišpondät 'одговарати' (од итал. 'rispondere'); danaǵawat < danaǵät ‘бити штетан' (од итал. 'danneggiare').

Супротно од тога, глаголи који су позајмљени из немачког језика допуштају префиксацију. Сличне појаве, тј. тенденцију ка суфиксацији и, обрнуто, префиксацији, у вези са позајмљеним глаголима романског и германског порекла приметио је и В. Број у молиско-словенском дијалекту, са једне стране (Breu 2003, 2005), као и у лужичкосрпском и градишћанско-хрватском - са друге.

Кључне речи: глаголски вид, морфологија, романске и германске позајмљенице, резјански дијалекат. 